\title{
РЕТРОСПЕКТИВНИЙ АНАЛІЗ ВИТОКІВ ПРАВОВОЇ КУЛЬТУРИ У ПЕДАГОГІЧНІЙ TEOPIÏ ВІД ЧАСІВ КИЇВСЬКОЇ РУСІ ДО ДРУГОї ПОЛОВИНИ ХІХ СТОРІччЯ
}

\footnotetext{
У статті здійснено аналіз історико-педагогічних питань правової культури у вітчизняній педагогічній думці. Визначено значення правового виховання у формуванні правової культури, правосвідомості.

Ключові слова: право, витоки правового виховання, правова свідомість, правова культура.

В статье осуществлён анализ зарождения вопросов правовой культуры в отечественной педагогической мысли. Определено значение правового воспитания в формировании правовой культуры, правосознания.

Ключевые слова: право, источники правового воспитания, правосознание, правовая культура.
}

Analysis of legal culture origin in national pedagogical belief has been made. Significance of legal education in legal culture forming and legal awareness has been defined.

Key words: law, legal education origin, legal awareness, legal culture.

В умовах розбудови Української держави, демократизації суспільного життя, побудови правового суспільства, відродження національної культури особливого значення набуває правова культура громадян, здатних будувати правове, громадянське суспільство і діяти за принципом конституційної демократії й поваги до прав людини.

Процес формування правової культури має давнє історичне коріння. Одночасно з виникненням держави та перших правових норм виникає й прагнення людини усвідомити своє місце і роль у правовій системі, сконструювати досконалі моделі правової поведінки [1, с. 88].

Проблему формування правової культури досліджували В. Дубровський, Г. Міньковський, В. Оржехівська, Є. Пєтухов, О. Пилипенко, М. Подберезський, М. Фіцула та ін., однак це питання залишається не дослідженим.

Актуальність обраної теми зумовлюється недостатньою іiі розробленістю в педагогічній науці, а також необхідністю використання історичного досвіду для подальшого вдосконалення процесу формування правової культури молоді.

Мета статті - дослідити розвиток ідей правової культури у вітчизняній педагогінній думці від часів Київської Русі до другої половини XIX сторіччя.

У Київській Русі процес формування правової культури був пов'язаний з поширенням правової освіти, здійснюваного через правове виховання. Про це, зокрема, свідчить зміст таких джерел, як «Руська правда» Ярослава Мудрого, «Слово о полку Ігоровім», «Повчання» Володимира Мономаха своїм дітям, «Слово про закон і благодать» митрополита Іларіона.

У зазначених документах розглядаються проблеми феодального права, поєднання політики із суспільною мораллю, відповідальності правителя, справедливості й законності, компетентності й опори на знання у правовій діяльності, припинення міжусобної боротьби й необхідності об'єднання руських земель.

Аналіз давньоруського судочинства дозволяє зробити висновок, що в школах підвищеного типу вивчався юридичний кодекс «Правда Руська». «Правда Руська» (XI-XII ст.) - збірка наших давніх законів. Вона кодифікувала соціальні й економічні відносини в умовах зростання приватної власності, усталювала права та обов'язки підданих. Створення цих законів мало прогресивний характер, бо ставилися перешкоди кровній помсті, уводилися однакові норми за певні злочини на всій території держави. Ці закони стали на цілі століття зразком, правилом, основою для будь-яких розпоряджень. [2, с. 48].

Норми «Руської правди» покладено в основу Псковської і Новгородської судових грамот, а також українського, білоруського та литовського права [3, с. 1022].

Наслідком діяльності Ярослава Мудрого було відкриття в Софії першої на Русі бібліотеки, скрипторія та школи, яку М. Грушевський назвав першою українською академію. Там вивчали граматику, риторику, піїтику, географію, математику, юриспруденцію тощо. Саме книжкові роботи Ярослава Мудрого надали Київській Русі можливість володіти основоположними працями Батьків Церкви, церковною і частково правовою літературою («Номоканони»), яка служила джерелом правового виховання громадян через здійснення їх правового навчання [4, с. 249].

За переконанням учених, найвищим досягненням педагогічної літератури Київської Русі $є$ «Слово о полку Ігоровім», яке стало втіленням загальноруського патріотизму, боротьби 3 іноземними загарбниками. У ньому відбилися думки й переживання кращих людей того часу, які добре зрозуміли, що лише за єдності всіх руських сил можна забезпечити захист рідної землі від ворожих нападів. Отже, за своїм ідейним спрямуванням «Слово о полку Ігоровім»- твір глибоко патріотичний, сповнений високих ідеалів служіння рідній землі [5, с. 23].

Разом із тим, він яскраво демонструє, що не можна нехтувати законами держави в ім'я власних 
інтересів, тим самим призводити до послаблення та занепаду країни.

Важливим документом «філософії освіти» Давньоруської держави були «Повчання Володимира Мономаха дітям» (1096) - перший в історії педагогіки педагогічний твір, написаний світською особою. «Повчання» вимагало виховання любові до Бога та страху Божого, суворого виконання церковних обрядів. У пам'ятці підтверджується патріархально-родовий характер виховання (порада поважати старших, оцінка батька як найвищого авторитету для дітей). Головним способом виховання визначалося наслідування дітьми батьків. В. Мономах неодноразово повторює настанови бути працелюбним, творити добро, навчатися й удосконалюватися. Як уособлений приклад виховного ідеалу висувається батько Мономаха - князь Всеволод, який вільно володів п’ятьма мовами. «Коли щось добре вмієте - не забувайте, а чого не вмієте - учіться, як це робив батько Володимирів. Сидячи дома вивчив п'ять мов і мав почесть від інших країн. Лінощі ж усьому лихому мати: що людина вміє - те забуде, а чого не вміє - того не вчиться» [6, с. 69].

В. Мономах закликав людей бути законослухняними. «Не наслідуй лиходіїв, не заздри тим, що творять беззаконня, бо лиходії винищені будуть, а ті, що надіються на Господа, заволодіють землею» $[6$, c. 38].

Отже, розглянута педагогічна пам'ятка проповідує загальнолюдські цінності, формує правові переконання та правову свідомість людини-громадянина.

За княжої доби функціонувала певна система освіти: діяли монастирські школи, які створювалися при монастирях, великих соборах. Монастирські школи для свого часу давали досить глибокі знання в галузі права. Ознайомлення учнів із церковним правом відбувалося за «Номоканоном».

3 погляду формування теорії правового виховання цікавою є ідея рівності всіх народів, що живуть на землі, висловлена у «Слові про Закон і Благодать» митрополитом Київським [7, с. 24].

«Це слово про закон, Мойсеєм даний, і про благодать та істину, що були Ісусом Христом, і як ця благодать всю землю сповнила, а віра на всі народи поширилася, і наш народ руський.» [6, с. 35].

3 усього зазначеного можемо зробити висновок, що до виникнення писаного права в українських землях побутувало звичаєве право, яке грунтувалось на моральній силі народних звичаїв, які впродовж багатьох віків зберігали свою сталість, історико-культурну й національну цілісність.

Правове виховання українського народу здійснювалося 3 урахуванням 2-х традицій права, які доповнювали одна одну, відрізняючись формальним, а не змістовними ознаками; це були норми звичаєвого й писаного права. Вони належали до системи християнської культури й зазнавали, особливо, відповідних впливів ззовні, з боку тих народів, 3 якими доводилося мати справу. Водночас на національному грунті традиційної української культури виникло звичаєве право, яке значною мірою забезпечувало вплив правових норм на процес правового виховання широкого загалу [4, c. 249].

Отже, витоки правового виховання у своїх первісних формах беруть початок за доби Київської князівської держави.

За часів українського національного відродження XVI-XVII століття центром розвитку шкільної освіти на Україні став Островський греко-слов'яно-латинський колегіум (1578 р.). Він сприяв появі братських шкіл. Братські школи працювали згідно зі статутом (нормативно-правовим актом того часу), прототипом для яких був статут Львівської братської школи - «Порядок шкільний». Статут став надбанням усіх братських шкіл, які існували в Україні. [8, с. 68].

Статути братських шкіл установлювали законне право навчання у школах всіх дітей братства, вводили обов'язкові правила шкільної поведінки, встановлювали застосування класно-урочної форми навчання, порядок зарахування дітей до школи, впроваджували певну участь громадськості у навчанні та вихованні молодого покоління. Так, у статуті Львівської братської школи (1586 р.) було записано: «Отцу о детях ... дискал и члены братства - смотрители школьные должны напоминать, чтобы дети дома вели себя соответственно..., показывая всем свою ученость и человечность...», а школа мала навчати їх «прилежным юношеским обычаям: как они должны вести себя в церкви перед Богом, дома перед родственниками своими и в других местах, добродетель и стыд хранить, высказывать Богу и его святым честь и страх, родным и дискалам послушание, всем покорность и уважение, себе самому чистоту и целомудрие». [9, с. 79-83].

Віддаючи дітей до школи, батько складав із ректором угоду, в якій вказувалось, чому повинна вчити школа дитину та визначалося коло обов'язків батьків у ставленні до школи, зумовлював якості, якими повинні володіти учителі. [10, с. $40-44]$.

Демократизм братських шкіл підтверджувався виборністю посади ректора та вчителів загальними зборами братства. Крім того, братство обирало двох попечителів - громадських спостерігачів за школою.

Поштовхом до подальшого розвитку правової культури, формування правової культури та правосвідомості народу в XVI - XIX століттях стала діяльність І. Вишенського, П. Орлика, Ф. Прокоповича, Г. Сковороди та ін.

Під час дослідження було встановлено, що важливе значення у формуванні правової культури українського народу мала діяльність видатного українського полеміста Івана Вишенського (15501620). Його твори мали велике значення у формуванні правосвідомості суспільства, бо в них 
I. Вишенський висував ідею захисту людської гідності й громадянських прав трудівників міста і села. I. Вишенський стверджував, що всі вони рівні незалежно від походження, суспільно-правового стану, оскільки їхнє тіло складається з єдиної субстанції - матерії. Не відступаючи від традиційного для свого часу тлумачення походження влади від Бога, письменник водночас наголошував на рівності носія влади й усіх людей. Зверхність його лише в даних йому владних повноваженнях. [2, с. 50].

Варто акцентувати й на тому, що важливу роль у формуванні правової культури українського народу відіграла Конституція П. Орлика, яка називалась «Пакти і Конституція прав і вольностей Війська Запорозького». (1710р.), у якій знайшли відображення ідеї самостійності України і права українського народу на власну державу. Поділу державної влади на законодавчу, виконавчу й судову. Конституція українського гетьмана П. Орлика була фактично першим у світі демократичним і гуманістичним законом такого типу. Ознайомлення сучасної молоді з гуманістичними положеннями козацької Конституції, яка захищала права українського народу, козацькі вольності, сприяе формуванню гордості за наших пращурів, що прагнули жити за законами добра, правди, краси.

Творча спадщина Ф. Прокоповича (1681-1736) досить значна і різноманітна. Справжній знавець античної та сучасної йому європейської культури він був енциклопедично обізнаним ученим і залишив значний слід в історії розвитку педагогічної думки в Україні і Росії. У творах «Духовний регламент» і «Правда волі монаршої» він висловив думку про те, що людина - це «об'єкт обов'язків і покори», яка завжди повинна підкорятися законам. Також було зазначено про важливість правових та інших знань. « Відомо всьому світові, як скудність і неміч була воїнства російського, коли воно не мало правильного собі навчання, і як незрівнянно умножилась сила його і над сповідання великою і страшною стала, коли державнійший наш монарх, його царська величність Петро I, навчив його добрим порядкам. Теж розуміти треба і про архітектуру, і про лікарство, і про політичне правління, i про всю решту справ».» [6, с. 35].

Великий вплив на розвиток правосвідомості українського народу мали твори українського просвітника, захисника ідей гуманізму й демократії - Г. Сковороди $(1722-1784)$, у яких він зображав безправне становище простого люду, їхнє прагнення до волі. Мандрівний філософ вірив у всемогутність людського розуму, розвиток якого, на його думку, здійснюється у процесі виховання $[5$, c. 23$]$.

Борцем за права і кращу долю простого люду був український поет, художник, мислитель, автор багатьох прогресивних теоретичних суджень про суть i форму держави, право і закон, право i соціальну справедливість, правосуддя і законність, а також історичних оцінок найважливіших етапів розвитку української державності Т. Шевченко (1814-1861). У низці творів поета розв'язуються філософсько-правові проблеми, що стосуються формування правової свідомості. [2, с. 51].

Витоки правової культури простежуються й у творчості українських письменників I. Котляревського, Г. Квітки-Основ'яненка та ін. Їхня творча спадщина мала велике значення для формування правової свідомості українського народу.

Так, І. Котляревський (1769-1838) звернув увагу на різницю у правовому становищі різних верств населення українського суспільства, підкреслював беззаконність дій чиновників.

Морально-правові питання розглядаються й у творах Г. Квітки-Основ'яненка (1787-1843), у яких засуджується свавілля сільських верховодів, їхні незаконні дії і вчинки, хабарництво суддів та інших представників влади [11, с. 45].

Отже, можемо зробити висновок про те, що питання розвитку і формування правової культури від часів Київської Русі до другої половини ХІХ ст хвилювали багатьох філософів, учених, мислителів, культурних і громадських діячів і формувалися на ідеях народної педагогіки, тобто джерела формування правової культури мають українські корені. Однак наукової теорії щодо розвитку і формування правової культури до зазначеного періоду не існувало.

\section{Література}

1. Кейзеров Н. М. Политика и правовая культура. Методологические проблемы / Н. М. Кейзеров. - М., 1983. - С. 88. 2. Українські витоки правового виховання /А. В. Стаников // Педагогічний альманах. - 2010. - № 6. - С. 48-51. 3. Енциклопедія освіти. - К. : Юрінком Інтер, 2008. - 1040 с. 4. Правове виховання в часи Київської Русі. [Електроний ресурс] / Г. П. Клімова. - Режим доступу: www. nbuv. gov. ua /portal/ soc_gum/pz 2009_103/103_40.pdf 5. Рацул О. Виховання громадянськості у студентів: історія та теорія: методичні рекомендації до вивчення спецкурсу / О. Рацул. - Кіровоград: ТОВ «Імекс ЛТД», 2005. - 72 с. 6. Історія української школи і педагогіки: хрестоматія / уклад.: О. О. Любар; за ред. В. Г. Кременя. - К. : Знання, 2005. 767 с. 7. Твердохліб Л. В. Формування правової культури старшокласників у навчальних закладах нового типу / Л. В. Твердохліб. - Луганськ: РВВ ЛАВС, 2003. - 263 с. 8. Любар О. Розвиток українського шкільництва і педагогічної думки в кайданах неволі / О. Любар, Р. Осипець // Рідна школа. - 2003. - №1 - С. 68. 9. Антология педагогической мысли Украинской ССР/ [антология / сост., Н. П. Калиниченко]. - М .: Педагогика, 1988. C. 79-83. 10. Чернов Ю. Братські школи України XVI-XVII ст. як унікальне явище народної творчості в системній організації педагогічного процесу / Ю. Чернов // Шлях освіти. - 2001. - №1. - С. 40-44. 11. Стаканков А. В. Теорія і практика правового виховання в історії вітчизняної педагогічної думки другої половини 19 - початку 20 століття: дис. ... канд. пед. наук: 13.00.01 / Стаканков Андрій Вікторович. - Х., 2003. $-207 \mathrm{c}$. 